MedieKultur | Journal of media and communication research | ISSN 1901-9726

Editorial

\title{
Platformed bodies
}

\section{Kristian Møller and Maja Nordtug}

MedieKultur 2021, 71, 1-8

Published by SMID | Society of Media researchers In Denmark | www.smid.dk The online version of this text can be found open access at www.mediekultur.dk

In "The politics of platforms", Tarleton Gillespie (2010) identifies how social media companies, during the 2000s, pivoted toward marketing their products as "platforms". He pinpointed what has now become common knowledge: that platformisation presents unique opportunities for businesses to create, control, and profit from markets, while simultaneously, in their consumer-facing communication, offering unique experiences of data-driven social connection with seemingly egalitarian and democratic infrastructures. The technological, social, and theoretical developments in the years since Gillespie's seminal piece have only made his analysis more relevant.

The popularisation of the platform perspective has joined, and to some degree displaced, other frameworks used to make sense of contemporary "network society" (Castells, 2010): frameworks like media infrastructure, ecology, logics, and industry (Fuchs, 2021). Conceptually, a substantial lack of clarity (or openness, depending on the generosity of the reading) remains. Platform analysis is typically taken to question "the coevolution of social media platforms and sociality in the context of a rising culture of connectivity" (van Dijck, 2013, p. 28). Inspired by Actor Network Theory (ANT) and political economy, van Dijck argues that to understand "platform society", we must identify both the techno-cultural and socioeconomic aspects of its operation and, crucially, have our analyses be informed by both. This analytical ethos and method has proven useful both for disassembling individual platforms as well as tracing sociality across platforms. 
With the abundance of social media, apps, devices, screens, sensors, virtual reality, and augmented reality - driven by a few extremely powerful and wealthy tech companies most spheres of life are intimately entangled with platforms' transnational and neoliberal organisation of sociability and commerce (Srnicek, 2017). Consequently, platformisation seems to be an ever-expanding mode of social organisation. In other words, platformisation has changed sensorial access to, and the conditions for, sociality and embodying identities. Crucially, what platform analysis reveals is how popular narratives of connection, sociality, and productivity do discursive work to obfuscate the inherent tensions and oppositions between the (increasing) disparity of value between owners and users. Arguably, studying embodiment, identities, and affect is crucial for understanding sociality and power in platform society. Thus, this special issue interrogates the conditions that allow contemporary platformed bodies to emerge, feel, act, and organise.

The role of technology for processes of embodiment, subjectification, and experience is a central problem in digital media and communication studies. After all, as Haraway (1991) describes in her cyborg figure, the body is always already a technological, heterogeneous assemblage of matters that should not be separated from the political and economic interests that made them possible in the first place. Like Haraway's cyborg, platformed bodies are constructed, in part, on the basis of digital materialities, affordances, and networks that are preconfigured so as to make bodies, their practices, and ultimately their work, produce outcomes that sustain the operation and proliferation of the platform. The body is the one thing we are all permanently "with" (Nettleton, 2013) and is therefore central to individuals' understanding of themselves. With the internet, the opportunities and requirements for considering one's own embodiment have increased (Shilling, 2012), changing the circumstances for how individuals experience their bodies (Tiidenberg \& Gómez Cruz, 2015). As such, media technologies are integral to how bodies are "lived, experienced, and continuously transformed" (Stage et al., 2020, p. 4). This arguably expands what counts as embodiment and, indeed, existence (Pedersen, 2017). Similarly, media platforms allow for specific ways of presenting the body (e.g., Klausen \& Grønning, 2021), and the way in which platforms categorise bodily traits may shape understandings and presentations of, for instance, race (Andreassen, 2020). Thus, what counts as a body is bound up with the materiality and opportunities offered by widely accessible media platforms. This is why efforts to understand the body and our relationship with it, as well as potential critiques of these understandings, demand studies that combine analyses of platforms and the body.

Historically, bodies and their affects in various technological configurations have been of central concern to much media and internet scholarship. Asking how bodies and embodiment emerge in the platform society, then, inscribes platform analysis into a history of media and internet scholarship. Questions of bodily placement, attention, emotion, and their markings have received attention in studies of media cultures, media domestication, and in ethnographies of everyday mediated lives, as well as in the ways 
that discourse and media systems produce and circulate ideas and representations that shape popular notions of what a body is, can, and should do. With digital media and the internet, online and offline embodiment, communication, and presence have become of great concern.

In current platform frameworks, however, the focus on generalised sociality and digital infrastructures, questions related to the body, its senses, and its politics have become somewhat peripheral or incidental. This is not to say that there is no work being done on the platformed conditions of embodiment. Indeed, several works have documented how these body politics play out in social media. In van Dijck's model however, it is unclear where or how to place, or rather assemble, the body. At first glance, it might simply be contained by "users and usage". With clear roots in ANT, it is not surprising that van Dijck chose to adopt this model and foreground sociality over bodies: the latter might simply read as human-centric, placing agency and explanatory power at the level of the individual, foreclosing the wonderful analytical and critical insights that network oriented, nonhuman-inclusive theories have created over the last several decades (see, e.g., Haraway, 1991; Deleuze \& Guattari, 1987; Barad, 1996; Latour, 2005; Hayles, 1999). Learning from these very theories, however, we would argue that when it comes to understanding the specific ways that platforms wield power over contemporary lives, centring the body is very useful. Judith Butler (1990) has made it clear that the body, its parts, sex, and even gender, as we know them, are made through language. The body as a unit of analysis and experience emerges in culture and language. Further, Robyn Longhurst reminds us that from a historical and macro political perspective:

In western culture, while white men may have presumed that they could transcend their embodiment (or at least have their bodily needs met by others) by seeing the body as little more than a container for the pure consciousness it held inside, this was not allowed for women, blacks, homosexuals, people with disabilities, the elderly and children. (Longhurst, 2000 p. 13)

To understand the struggle over sensuality and subjectification, research must disassemble their very production, and ask how affect, identity work, and governance play out in body work and in body representations. The platformed body can emerge across multiple sites, operating in or across different material scales, much akin to what Deleuze and Guattari address through their "body-without-organs" concept (Deleuze \& Guattari, 1987). Extending Morley's (2008) analytical proposition of "non-media centricity", one may take a more or less platform-centric approach, depending on which sorts of relations one aims to reveal.

Platformed body analysis asks the deceptively simple questions: How do bodies emerge in relationship to platforms, and what can a platformed body do? What is the body's relationship to platform content, technological infrastructure, its user base, as well as ownership structure and modes of governance? By centring bodies over sociality in 
platform analysis, the contributions to this special issue explore how senses, experience, and identity in contemporary digital media landscapes are continuously made and configured, their existence and engagement with the world never final, never self-contained. This helps us understand how the immediacy of the body is entangled with infrastructures that make contemporary lives possible to begin with. Following van Dijck's model of platform analysis, several aspects, or "micro systems", are considered in tandem, interrogating flows between, say, users and technologies, or types of content and modes of governance. Consequently, the contributions show how, in flows between platform micro systems, bodies are produced, performed, assembled, valued, and othered.

\section{Contributions to the special issue}

The nine articles that constitute this special issue present different perspectives on the platformed body. In the contributions, very different sites and scales of contemporary bodily representation and work are considered, including: intimacy and sex work on the social media site OnlyFans; hair regain communities and excessive and spectacular eating practices (mukbang) on YouTube; sensual intensities and politics of teledildonics; processes of citizen responsibilisation in e-mail consultation platform-mediated with general practitioners; practices of period tracking and (re)constituting cycles; unaccompanied refugee youth's work of extending bodily communication through digital acts; boys and young men's use of sexualised, platformed female bodies to negotiate boundaries of masculinity, gendered positioning, and intimacy; and the production of collective, unruly, and becoming bodies in trying-to-conceive communication on Instagram. The sheer variety in both subject matter and scale at which the body is conceived is at once a testament to the importance of body-centred research, the broad applicability of platform analysis, and ultimately, we would argue, the immense need for examining the platformed body.

In the article "Embodied technology use: Unaccompanied refugee youth and the migrant platformed body", Annamária Neag and Julian Sefton-Green show the ways in which unaccompanied refugee youth's digital actions function as extensions of bodily communication. Specifically, through participant observation, semi-structured interviews, digital ethnography, and participant action research, Neag and Sefton-Green provide insights into the ontological existence of the migrant platformed body by focusing on (re) settlement, food, music, and religion.

Kristina Stenström and Katarina Winter explore what material-discursive bodies emerge in trying-to-conceive (TTC) communication. The article, "Collective, unruly and becoming: Bodies in and through TTC communication", draws on online ethnographic explorations of Swedish TTC communication on Instagram, including observation of 394 Instagram accounts and close analysis of 100 posts. Stenström and Winter find that the bodies that emerge through this platform are collective bodies, unruly bodies, and becoming bodies. 
In the article "Materializing: Period-tracking with apps and the (re)constitution of cycles", Victoria Andelsman explores how menstruating bodies emerge in relation to selftracking technologies. Based on thirteen in-depth interviews with period-tracking app users living in the Netherlands, Andelsman shows how period-tracking apps reshape app users' experiences of their menstruating bodies.

Pernille Rasmussen and Dorte Marie Søndergaard pay much needed attention to how boys and young men share, trade, and evaluate sexualised images of female bodies. The article, "Sexualized platformed female bodies in male online practices: Negotiating boundaries of masculinity, gendered positioning, and intimacy", draws on digital ethnography as well as analogue fieldwork and interviews with young people. Rasmussen and Søndergaard argue that the platformed female body mostly functions as an object the boys and young men use to negotiate their gender positioning.

Another exploration of platformed sexuality, "The bodies of the (digitised) body: Experiences of sexual(ised) work on OnlyFans", by Cosimo Marcello Scarcelli and Daniel Cardoso, offers timely insight into a platform whose facilitation of digital sex work has seen immense growth during the Covid-19 pandemic. Identifying the corporeal, technical, and self-transformational work done by female performers, they find that bodily platformisation on OnlyFans was generative of both self-appreciation and exhaustion, calling attention to the way embodiment is bound up with self-entrepreneurship and authenticity work.

Turning towards another intensely corporeal platformed phenomenon, "Regarding the mains of others: The spectacular bodies of mukbang videos", by Louise Yung Nielsen and Franziska Bork Petersen, investigates the affective workings of a contemporary social video genre focused on (excessive) eating. Drawing from aesthetic theories of contagion and empathy, and conceiving of media as performative, the authors trace how food consumption, audiovisual aesthetics, media technologies, and platform logics all become constituents of the spectacular body's performance within the attention economy of YouTube.

In another excellent contribution on platformed affectivity, Marilia Kaisar probes "Bluetooth orgasms", that is, the relationship between interactive sex toys and the bodies they affect. Drawing on Brian Massumi's work on virtuality and affect, they hone in on the "complex technological and biological assemblages, where vibrating machines and the human body's flesh come into intimate connection through datafication".

In "The mediatization of self-tracking: Knowledge production and community building in YouTube videos", Michael Nebeling Petersen and Tobias Raun investigate hair growth communities, particularly the positional knowledge work of channel owners. With knowledge production outlined as either expert or practitioner-based, and with users participating as either community leaders or members, the article offers a useful generic model for making sense of mediated self-tracking communities and practices at large. 
Finally, in "'Therefore, I would like an allergy test': Responsibly conducting a healthy body through the e-mail consultation platform", Maja Nordtug, Matilde Nisbeth Brøgger, and Jane Ege Møller explore whether and how the e-mail consultation platform provides opportunities for patients to be active and responsible biological citizens. Based on an analysis of 646 e-mail consultations, Nordtug, Nisbeth Brøgger, and Møller identify four modes in which patients are able to enact biological citizenship through the platform, namely by affirming their own responsibility in healthcare, making suggestions to their general practitioner, making requests of their general practitioners, and questioning aspects of healthcare.

Together, the contributions demonstrate that platforms do significantly alter bodily capacities to act and feel, and that this depends on the identities that attach to these bodies as well as, to some extent, their socioeconomical circumstances. Thus, the issue as a whole harnesses the power of van Dijck's techno-cultural analysis to assemble technology, users and usage, and content (van Dijck, 2013). By the same token, socioeconomic structures, questions of platform ownership, governance, and business models remain underexplored, thus inviting further research. Nevertheless, it seems clear that the expansive nature of platform analysis is useful for bringing together the many ways that bodies materialise and how their capacities are actualised with and through digital infrastructures. Consequently, we hope this special issue can strengthen critical interventions at this level.

\section{Open section}

\section{Stinne Gunder Strøm Krogager}

The issue also includes two open section articles and two book reviews. In the article "Mål, middel og tid - om livsformsanalysen som metode til at studere tilgangen til nyheder og aktualitetsstof", Jakob Linaa Jensen and Jakob Dybro Johansen discuss how to study Danes' perception of the news. Empirically, the article is based on a large quantity of in-depth interviews and a survey, with which the authors argue that demographic factors that are usually applied in studies of news consumption do not fully explain different approaches to news. These relations depend on a variety of personal and everyday life factors.

In "Collaborative domestication: How patients account for their experience of video consultations with their general practitioner", Elle Christine Lüchau and Anette Grønning propose an extension to domestication theory by introducing the concept of collaborative domestication. Through interviews with patients in Denmark, the authors find that both individual and relational factors impact patients' views on video consultations with their general practitioner.

In the first book review, Anders Bonde reviews Vores æestetiske kategorier - Det gakkede, det nuttede og det interessante (2021), the recently published Danish translation 
of Siane Ngai's Our Aesthetic Categories: Zany, Cute, Interesting (2012). Building on traditional philosophical aesthetics, Ngai focusses on people's affective, communicative, and intimate handling of cultural products, arguing that the three aesthetic categories (the zany, the cute, and the interesting) saturate postmodern culture.

In the second book review, Anders Kristian Munk reviews the collected volume "Data Visualization in Society", edited by Martin Engelbertsen \& Helen Kennedy (2020). The anthology discusses what data visualisation does to our society, and the 26 comprised chapters approach the question from diverse perspectives, including semiotics, data literacy, and narration, as well as what it means to live and work with data, and how inequalities are entrenched in different kinds of visualisation.

\section{References}

Andreassen, R. (2020). Digitale sorteringskategorier, affordances og interfaces. In: R. Andreassen, R. R. Pedersen, \& C. Svanbo (Eds.), Digitale liv. Roskilde Universitetsforlag.

Barad, K. (1996). Meeting the universe halfway: Realism and social constructivism without contradiction. In Feminism, science, and the philosophy of science (pp. 161-194). Springer, Dordrecht.

Butler, J. (1990). Gender trouble: Feminism and the subversion of identity (1st ed.). Routledge. https://doi. org/10.4324/9780203824979

Castells, M. (2010). The rise of the network society. Wiley Online Library. https://doi. org/10.1002/9781444319514

Deleuze, G., \& Guattari, F. (1987). A thousand plateaus: Capitalism and schizophrenia. University of Minnesota Press.

Engelbertsen, M., \& Kennedy, H. (2020). Data Visualization in Society. Amsterdam University Press. https:// doi.org/10.2307/j.ctvzgb8c7

Fuchs, C. (2021). Social media: A critical introduction. Sage. https://www.doi.org/10.4135/9781446270066

Gillespie, T. (2010). The politics of 'platforms'. New Media \& Society, 12(3), 347-364. https://doi. org/10.1177/1461444809342738

Haraway, D. J. (1991). Simians, cyborgs, and women: The reinvention of nature. Routledge. https://doi. org/10.4324/9780203873106

Hayles, N. K. (1999). How we became posthuman: Virtual bodies in cybernetics, literature, and informatics. University of Chicago Press.

Klausen, M., \& Grønning, A. (2021). My throat "tickles". Conjunctions, 8(1), 1-17. https://doi.org/10.7146/ tjcp.v8i1.123038

Latour, B. (2005). Reassembling the social: An introduction to actor-network-theory. Oxford University Press. Longhurst, R. (2000). Bodies: Exploring fluid boundaries. Routledge. https://doi.org/10.4324/9780203193600 Morley, D. (2008). For a materialist, non-media-centric media studies. Television \& New Media, 10(1), 114-116. https://doi.org/10.1177/1527476408327173

Ngai, S. (2012). Our aesthetic categories: Zany, cute, interesting. Harvard University Press.

Ngai, S. (2021). Vores cestetiske kategorier - Det gakkede, det nuttede og det interessante [Our aesthetic categories: Zany, cute, interesting] (P. Borum, Trans.). Ny Carlsbergfondet.

Nettleton, S. (2013). The sociology of health and illness (3rd ed.). Polity Press. 
Editorial: Platformed bodies

Pedersen, I. K. (2017). Krop og kultur. In: P. T. Andersen, M. H. \& Jacobsen (Eds.), Kultursociologi og kulturanalyse. Hans Reitzels Forlag.

Shilling, C. (2012). The body \& social theory (3rd ed.). Sage.

Srnicek, N. (2017). Platform capitalism. John Wiley \& Sons.

Stage, C., Hvidtfeldt, K., \& Klastrup, L. (2020). Vital media: The affective and temporal dynamics of young cancer patients' social media practices. Social Media + Society, 6(2), 1-13. https://doi. org/10.1177/2056305120924760

Tiidenberg, K., \& Gómez Cruz, E. (2015). Selfies, image and the re-making of the body. Body \& Society, 21(4), 77-102. https://doi.org/10.1177/1357034X15592465

van Dijck, J. (2013). The culture of connectivity: A critical history of social media. Oxford University Press. https://doi.org/10.1093/acprof:oso/9780199970773.001.0001

Kristian Møller

Assistant professor

Department of Communication and Arts

Roskilde University

kristianm@ruc.dk

Maja Nordtug

Research assistant

Department for the Study of Culture

University of Southern Denmark

majan@sdu.dk 